\title{
Loop-mediated isothermal amplification (LAMP): Early detection of Toxoplasma gondii infection in mice
}

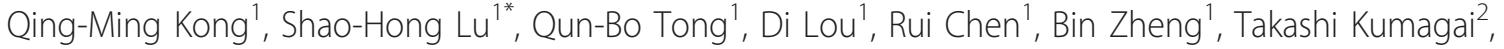 \\ Li-Yong Wen ${ }^{1}$, Nobuo Ohta ${ }^{2}$ and Xiao-Nong Zhou ${ }^{3}$
}

\begin{abstract}
Background: Toxoplasmosis is a widespread zoonotic parasitic disease that occurs in both animals and humans. Traditional molecular assays are often difficult to perform, especially for the early diagnosis of Toxoplasma gondii infections. Here, we established a novel loop-mediated isothermal amplification targeting the 529 bp repeat element (529 bp-LAMP) to detect T. gondii DNA in blood samples of experimental mice infected with tachyzoites of the $\mathrm{RH}$ strain.
\end{abstract}

Findings: The assay was performed with Bst DNA polymerase at $65^{\circ} \mathrm{C}$ for $1 \mathrm{~h}$. The detection limit of the $529 \mathrm{bp}$ LAMP assay was as low as $0.6 \mathrm{fg}$ of $T$. gondii DNA. The sensitivity of this assay was 100 and 1000 fold higher than that of the LAMP targeting B1 gene (B1-LAMP) and nested PCR targeting $529 \mathrm{bp}$ repeat element (529 bp-nested $P(R)$, respectively. The specificity of the 529 bp-LAMP assay was determined using the DNA samples of Trypanosoma evansi, Plasmodium falciparum, Paragonimus westermani, Schistosoma japonicum, Fasciola hepatica and Angiostrongylus cantonensis. No cross-reactivity with the DNA of any parasites was found. The assay was able to detect T. gondii DNA in all mouse blood samples at one day post infection (dpi).

Conclusions: We report the following findings: (i) The detection limit of the $529 \mathrm{bp}$-LAMP assay is $0.6 \mathrm{fg}$ of $T$. gondii DNA; (ii) The assay does not involve any cross-reactivity with the DNA of other parasites; (iii) This is the first report on the application of the LAMP assay for early diagnosis of toxoplasmosis in blood samples from experimentally infected mice. Due to its simplicity, sensitivity and cost-effectiveness for common use, we suggest that this assay should be used as an early diagnostic tool for health control of toxoplasmosis.

\section{Findings}

Approximately one third of the global human population is infected with T. gondii, including populations in Europe, South America, Africa and several Asian countries [1-3]. This parasite can cause congenital toxoplasmosis in a developing fetus and is dangerous for patients with acquired toxoplasmosis and compromised immune systems, such as patients with acquired immune deficiency syndrome (AIDS) or patients undergoing organ transplantation [4,5]. Congenital transmission of this parasite is found in a large variety of wild animal species and livestock, such as sheep, goats, pigs,

\footnotetext{
*Correspondence: Ilsshh2003@163.com

'Institute of Parasitic Diseases, Zhejiang Academy of Medical Sciences, Hangzhou 310013, China

Full list of author information is available at the end of the article
}

and cattle [6,7]. Ingestion of infected pork is considered to be the main source of $T$. gondii infection in humans in the United States [8]. T. gondii is also recognized as a major cause of abortion in farm livestock such as sheep, goats, pigs, and other domestic animals [5,9].

The diagnosis of $T$. gondii infection or toxoplasmosis can be established by isolation of the parasite, histological examination, serological tests, or polymerase chain reaction (PCR). Biological diagnosis classically relies upon serological examination and direct detection of the parasite by inoculation of laboratory animals. A serological assay is considered the most challenging procedure because specific antibodies may not be present in the early stages of infection, especially in immune deficient or pregnant patients [10]. Nested PCR, real-time PCR and LAMP assays have been used to detect $T$. gondii

\section{() Biomed Central}


DNA in animal materials [11], water [12], soil [13], and clinical specimens [14]. In the past decade, the use of PCR has resulted in a significant improvement in both the prenatal diagnosis of congenital toxoplasmosis and the detection of acute disease in immunocompromised patients. Among these PCR techniques, nested PCR, followed by hybridization, has been reported to be the most sensitive assay for detection [15]. Real-Time PCR to detect toxoplasmosis not only can quantify $T$. gondii in biological samples but also has superior sensitivity over nested PCR assays [16,17]. Despite these advances, diagnosis of $T$. gondii infection remains unsatisfactory because PCR-toxoplasma assays have not yet attained a sufficient level of sensitivity, and are limited due to expensive equipment and long reaction time periods.

LAMP is one of the nucleic acid amplifications tests used in various fields, including infection diagnosis to identify organisms. This assay uses a DNA polymerase called Bst polymerase, which has displacement activity and a set of four specially designed primers that recognize a total of six distinct sequences of the target DNA [18]. It has been used to perform highly specific and sensitive amplifications of DNA to detect pathogens including viruses, bacteria, protozoa, and fungi. Recently, this technique has proven to be very useful in the diagnosis of parasitic infections, such as malaria, trypanosomiasis, dirofilariasis, and babesiosis [19-22]. Rapid detection of $T$. gondii in water samples by LAMP was first described in a study by Sotiriadou et al. [23]. Thereafter, the LAMP assay was developed and evaluated for the detection of $T$. gondii infection from the lymph nodes of pigs [24], various organs harvested from mice [25], and blood samples from patients [26].

In the present study, we developed a LAMP assay targeting the 529 bp repeat element for the detection of $T$. gondii. Furthermore, we evaluated the detection sensitivity of T. gondii LAMP in comparison with conventional nested PCR. This is the first report in which the LAMP assay has been used for early diagnosis of active toxoplasmosis in mouse blood samples.

Development and optimization of the $\mathbf{5 2 9}$ bp-LAMP assay The choice of gene sequence is critical when establishing a diagnostic method for molecular tests. Multicopy sequences specific for $T$. gondii, such as the $B 1$ gene or the 529 bp sequence used in this study, are especially useful in molecular tests [27]. For the detection of $T$. gondii, the sequence most frequently used is the $B 1$ gene, first identified in 1989 by Burg et al. [28], of which there are 35 copies in the genome. The newly described 529 bp repeat element is repeated more than 300 -fold in the genome of $T$. gondii. On the basis of the sequence for the $529 \mathrm{bp}$ repeat element in GenBank (AF146527.1), one primer set for use in the LAMP assay and a second set for the nested PCR were designed. The location and sequence of each primer targeting this repeat element for $T$. gondii detection are shown in Figure 1.

The procedures for the LAMP and nested PCR methods were carried out according to the description by Lau et al. [26]. The 529 bp-LAMP assay was performed using the Loopamp DNA amplification kit (Eiken Chemical Co. Ltd., Tokyo, Japan). In brief, the assay was performed with the following optimized reaction mixture: $25 \mu \mathrm{l}$ of a mixture containing $12.5 \mu \mathrm{l}$ of $2 \times$ reaction mix buffer, $1 \mu$ l of the extracted DNA of $T$. gondii RH strain, $40 \mathrm{pmol}$ (each) of primers FIP and BIP, 5 pmol of primers B3 and F3, and $1 \mu$ l of Bst DNA polymerase. To determine the optimal conditions for sensitivity and selectivity, the LAMP reactions were performed at a range of temperatures $(61,63,65,67$ and $69^{\circ} \mathrm{C}$ ) for different time periods $(40,50,60,70$ and $90 \mathrm{~min}$ ). The best result was obtained when the reaction temperature was maintained at $65^{\circ} \mathrm{C}$ for $60 \mathrm{~min}$ (Data not shown). All positive LAMP reactions produced a typical ladder of multiple bands on the 1.5\% agarose gel stained with GelRed ${ }^{\mathrm{TM}}$ (Biotium Inc.) (Figure 2E), which indicated the production of stem-loop DNA with inverted repeats of the target sequence. Furthermore, positive reactions turned green on addition of SYBR Green I to reaction tubes, while the tubes showing negative reactions remained orange. The first round of 529 $b p$-nested PCR amplification contained $10 \mu \mathrm{l} 2 \times$ Taq PCR MasterMix (0.1 U Taq Polymerase, $500 \mu \mathrm{M}$ dNTP each, $20 \mathrm{mM}$ Tris- $\mathrm{HCl}, \mathrm{pH} 8.3,100 \mathrm{mM} \mathrm{KCl,} 3 \mathrm{mM}$ $\mathrm{MgCl}_{2}$ ), $0.3 \mu \mathrm{l}$ of the $5 \mu \mathrm{M}$ primers NF1 and NR1 (Fig-

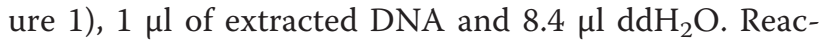
tions were cycled 30 times by denaturation at $94^{\circ} \mathrm{C}$ for 1 min, followed by annealing at $60^{\circ} \mathrm{C}$ for $30 \mathrm{~s}$ and a final extension step at $72^{\circ} \mathrm{C}$ for $40 \mathrm{~s}$. The first round product was diluted 1:100. The second round of PCR mixtures contained $2 \mu$ ldiluted product, $10 \mu \mathrm{l} 2 \times$ Taq PCR MasterMix, $1 \mu \mathrm{l}$ of each $5 \mu \mathrm{M}$ primer NF2 and NR2, and 6 $\mu \mathrm{lddH_{2 }}$ O. The second round PCR was cycled 35 times by denaturation at $94^{\circ} \mathrm{C}$ for $10 \mathrm{~s}$, followed by annealing at $50^{\circ} \mathrm{C}$ for $15 \mathrm{~s}$ and a final extension step at $72^{\circ} \mathrm{C}$ for $20 \mathrm{~s}$. The PCR products of $164 \mathrm{bp}$ for the positive reaction appeared on the $1.5 \%$ agarose gel stained with GelRed $^{\text {TM }}$ (Biotium, Inc.) (Figure 2C).

\section{LAMP sensitivity and specificity}

T. gondii tachyzoites ( $\mathrm{RH}$ strain) were propagated in vitro under standard procedures by serial passages in HeLa cell monolayer in Dulbecco's modified Eagle medium (DMEM, Invitrogen) supplemented with $2 \%$ fetal bovine serum at $37^{\circ} \mathrm{C}$ under $5 \% \mathrm{CO}_{2}$ (Figure $2 \mathrm{~A}$ ). Tachyzoites were collected by scraping the cell monolayer and washing with cold phosphate-buffered saline 
A NF1

61 ttgtttttt tgacteggge ccagetgegt ctgtcgggat gagaccgcgg agcegaagtg aacaaaaaa actgagcceg ggtcgacgca gacagcceta ctctggegcc tcggettcac

181 cacagaaggg acagaagtcg aaggggacta cagacgcgat gecgetcctc cagcegtctt gtgtcttcce tgtcttcage ttcccetgat gtctgegeta cggegaggag gtcggcagaa

301 tgggaagcga cgagagtcgg agagggagaa gatgttccg gettggetg accettcget getctcagec tctccetctt ctacaaagge cgaaccgacg aaaggacc

361 gggtggaaaa agagacaccg gaatgcgatc cagacgagac gacgetttcc tcgtggtgat cccaccttt tetctgtggc cttacgctag gtctgetctg ctgcgaaagg agcaccacta

\section{F1c 4}

421 ggcggagaga attgaagagt ggagaagagg gcgagggaga cagagtcgga ggettggacg cegectetet taacttctca cetctetce cgetcectet gtcteagect cegaacetge

\section{B2}

481 aagggaggag gaggggtagg agaggaatcc agatgcactg tgtctgcag ttcectcetc ctcccatcc tctcettagg tctacgtgac acagacgtc

\section{NR1} $\mathrm{B} 3$

$\mathrm{B}$

\begin{tabular}{ll}
\hline Primer & \multicolumn{1}{c}{ Sequence $\left(5^{\prime} \longrightarrow 3^{\prime}\right)$} \\
\hline Nested-PCR & \\
NF1 & TGACTCGGGCCCAGCTGCGT \\
NR1 & CTCCTCCCTTCGTCCAAGCCTCC \\
NF2 & AGGGACAGAAGTCGAAGGGG \\
NR2 & GCAGCCAAGCCGGAAACATC \\
LAMP & \\
F3 & ACGAGAGTCGGAGAGGGA \\
B3 & TGGATTCCTCTCCTACCCCT \\
FIP (F1c-F2) & GGATCGCATTCCGGTGTCTCTTAAGATGTTTCCGGCTTGGC \\
BIP (B1c-B2) & GACGACGCTTTCCTCGTGGTCAAGCCTCCGACTCTGTCT \\
\hline
\end{tabular}

Figure 1 Location and sequence of LAMP primer sets targeting the $\boldsymbol{T}$. gondii $\mathbf{5 2 9}$ bp repeat element. (A) Partial sequence of T. gondii 529 bp repeat element and the location of four primers: F3, B3, FIP (F1C-F2) and BIP (B1C-B2). Arrows indicate the direction of extension; numbers on the left indicate the nucleotide position. (B) Sequence of primers for Nested-PCR LAMP reaction.

(PBS). The final pellet was resuspended in cold PBS and passed three times through a 30 -gauge needle syringe. Clarification and all subsequent centrifugations were performed at $4^{\circ} \mathrm{C}$. The parasites were then diluted with $1.0 \mathrm{ml} \mathrm{PBS}$ and centrifuged to equilibrium in $13 \mathrm{ml}$ non-linear $10 \%-50 \%$ Percoll density gradients at 2,500 $\times g$ for $20 \mathrm{~min}$. Purified parasites were diluted with PBS and pelleted by sedimentation at 2,500 $\times g$ for $20 \mathrm{~min}$ to remove the Percoll. The purity of parasites was confirmed microscopically to ensure that the tachyzoites 


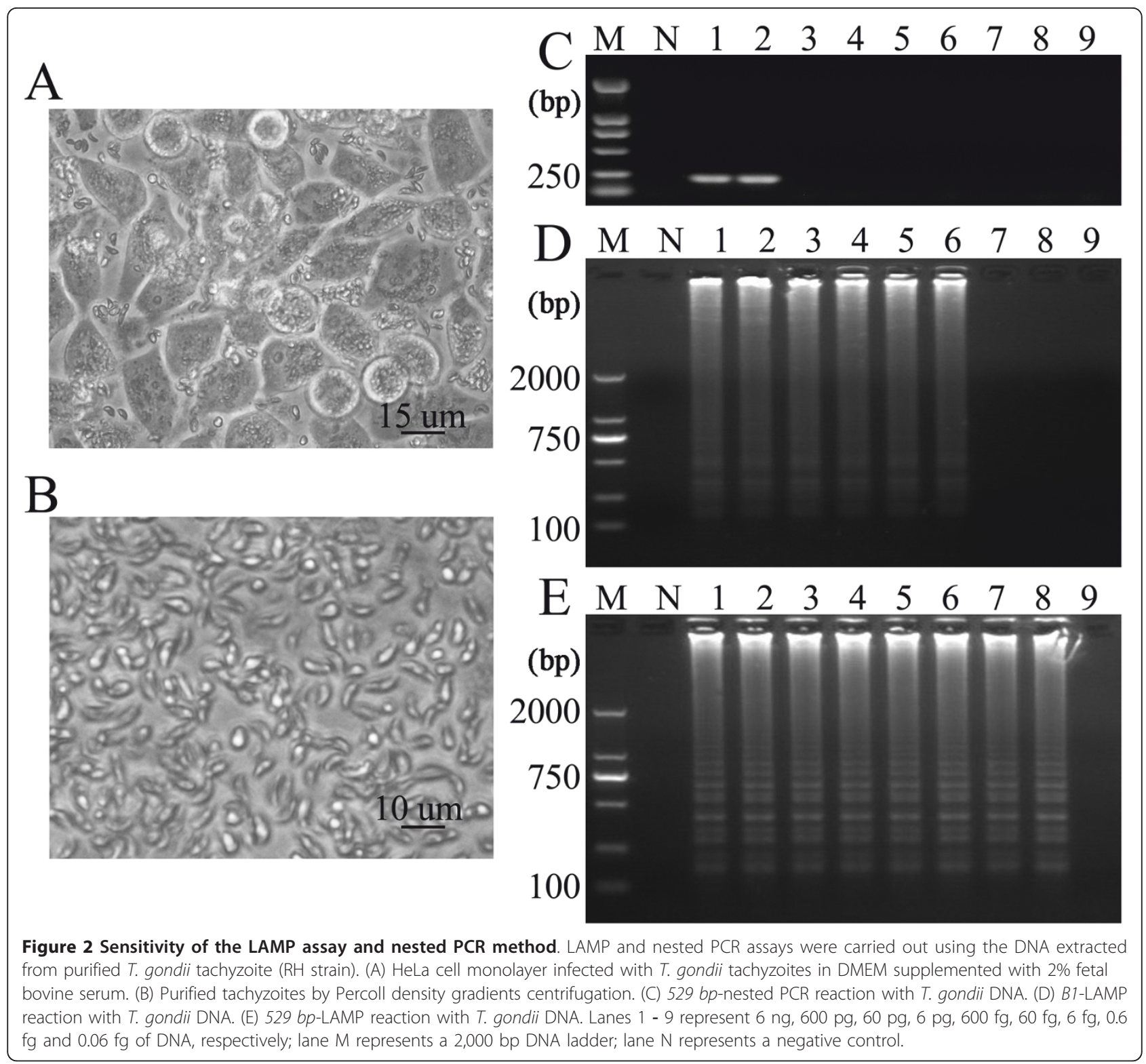

had normal morphology and to exclude the possible inclusions of other cellular organelles and debris (Figure 2B). Tachyzoite genomic DNA extracted with DNeasy Blood \& Tissue Kit (QIAGEN, Maryland, USA) was used in concentrations ranging from $6 \mathrm{ng}$ to $0.06 \mathrm{fg}$. Three replicate assays showed high reproducibility of the LAMP and nested PCR. The DNA extraction procedure did not affect the sensitivity of the LAMP and PCR.

The sensitivity of the $529 b p$-LAMP assay was determined and compared to the results of the $529 \mathrm{bp}$-nested PCR and the B1-LAMP. The LAMP products in positive reaction tubes were visually detectable on addition of SYBR Green I to the reaction tube. On gel electrophoresis, the amplified products showed ladder-like patterns.
The detection limit of the $529 b p$-LAMP assay was 0.6 fg of $T$. gondii DNA (Figure 2E). In contrast, the detection limit of B1-LAMP was $60 \mathrm{fg}$ of the DNA template (Figure 2D) and the limit of the $529 b p$-nested PCR was $600 \mathrm{fg}$ of the DNA template (Figure 2C). Therefore, it appears that the sensitivity of the $529 \mathrm{bp}$-LAMP assay was 100 fold higher than that of the B1-LAMP assay and was 1000 fold higher than that of the $529 \mathrm{bp}$-nested PCR. These results demonstrate that the primers based on the 529 bp repeat element are more suitable than those based on the $B 1$ gene. This supported by the finding that the sensitivity of the quantitative LightCycler PCR assay targeting the $529 \mathrm{bp}$ repeat element of $T$. gondii is about 10 to 100 -fold higher than that targeting the $B 1$ gene [29]. The sensitivity of LAMP assay is 
higher than that of the conventional PCR for detection of protozoan parasites such as Babesia spp., Theileria spp., Trypanosoma spp., which has been reported previously [30-32].

The specificity of the LAMP assay was tested by using the DNA samples of other parasites. No amplification was observed in the DNA samples of Trypanosoma evansi, Plasmodium falciparum, Paragonimus westermani, Schistosoma japonicum, Fasciola hepatica and Angiostrongylus cantonensis (Figure 3), which proved that the LAMP primers are highly specific for the detection of $T$. gondii.

Application of LAMP to blood samples from infected mice Six-week old BALB/c mice (Purchased from the Zhejiang Provincial Experimental Animal Center, China) were infected by intraperitoneal injection of 20 virulent tachyzoites of the T. gondii RH strain (Stored in our laboratory). Blood samples were collected at 1, 3, and 5 dpi from the vena orbitalis posterior plexus blood. The DNA was extracted from blood samples of infected mice by using DNeasy Blood \& Tissue Kit (QIAGEN, Maryland, USA) according to the manufacturer's instructions. The use of animals was approved by the Institutional Animal Care and Use Committee (IACUC) of Zhejiang Academy of Medical sciences. The purified DNA from $50 \mu \mathrm{l}$ blood samples was dissolved in $30 \mu \mathrm{l}$ of double-distilled water and $1 \mu \mathrm{l}$ of the resulting supernatant was used as the template for the subsequent detection. The DNA extracted from the blood samples of the uninfected mice was used as negative control. In order to exclude the presence of inhibitors in blood samples, we selected a pair of PCR primer
(F: 5'-TCAAGAACGAAAGTCGGAGT-3';

R: 5'-GGACATCTAAGGGCATCACA-3') to amplify a mouse 18s rRNA fragment (GenBank Accession No. NR_003278.2), with an amplified zone of the target is $489 \mathrm{bp}$ [33]. We also chose mouse 18s rRNA as an internal control target. The primers for internal control are as follows,

\section{F3: 5'-GAATCAGGGTTCGATTCCGG-3';}

B3: 5'-GAATTACCGCGGCTGCTG-3';

FIP: 5'-AGTGGGTAATTTGCGCGCCTGAGAGGGAGCCTGAGAAACG-3';

BIP: 5'-CAGGACTCTTTCGAGGCCCTGTGCCCTCCAATGGATCCTC-3'.

Analysis of the nine blood samples by the $529 \mathrm{bp}$ LAMP assay and $529 b p$-nested PCR revealed some differences in the sensitivity of both the assays. The 529 $b p$-LAMP assay showed positive results for all blood samples from infected mice. The nested PCR assay showed DNA fragments of appropriate sizes from six blood samples (Figure 4). The negative control of uninfected mouse did not show amplification of DNA fragments by LAMP and nested PCR. Internal control reaction was visually observed which confirmed that there were no inhibitors in blood samples. In mouse inoculated with tachyzoites of RH strain, the parasites were first detected by the nested PCR assay at $3 \mathrm{dpi}$, while the earliest detection of parasite DNA by $529 \mathrm{bp}$ LAMP assay was at $1 \mathrm{dpi}$, which demonstrated that the LAMP assay was effective for an earlier diagnosis. In a recent report, the $B 1$-based LAMP assay had a higher sensitivity $(80 \%)$ than nested PCR $(62.5 \%)$ in diagnosing toxoplasmosis in human blood samples [26]. To analyze the diagnostic sensitivity and specificity of the LAMP

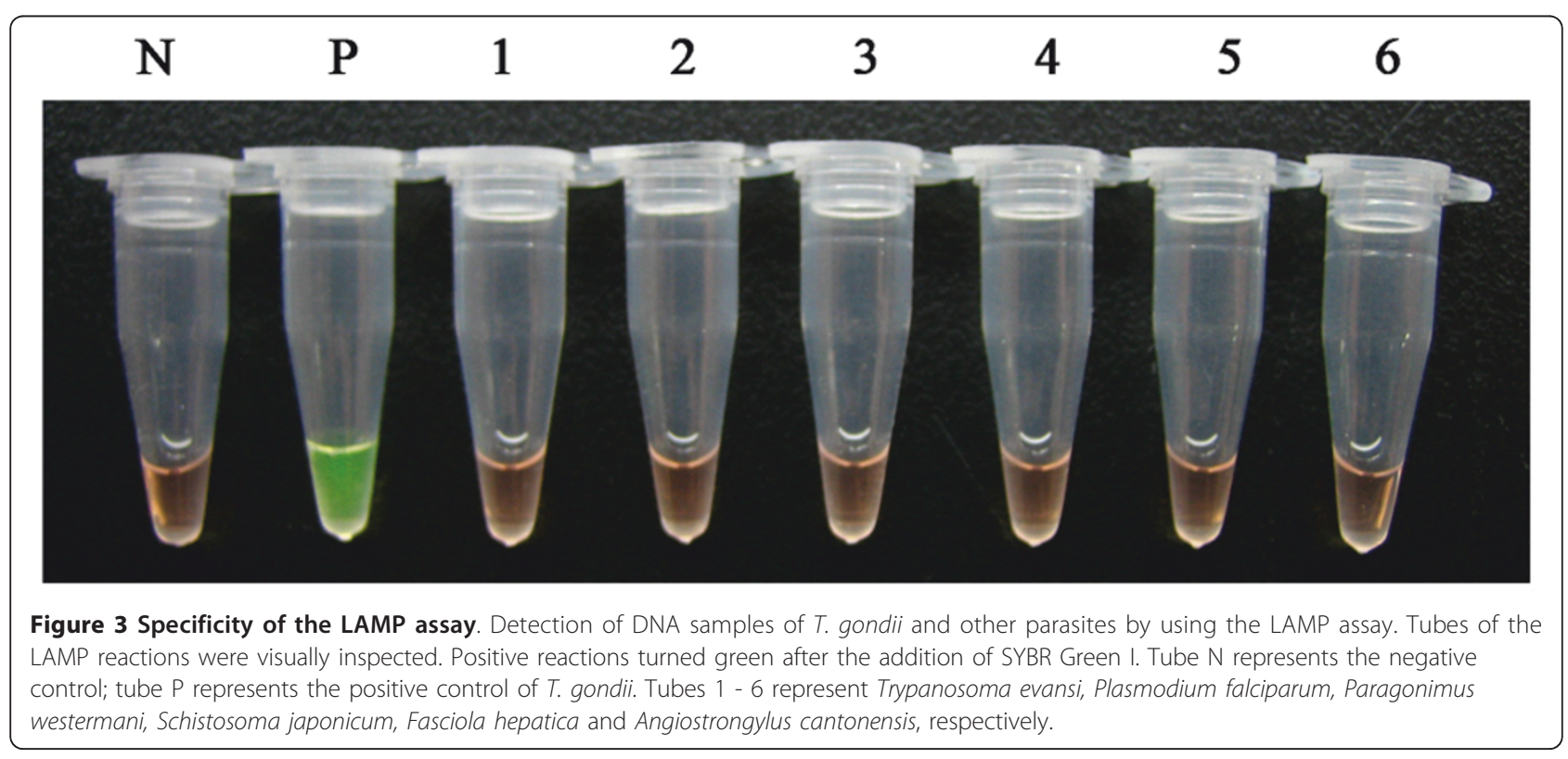




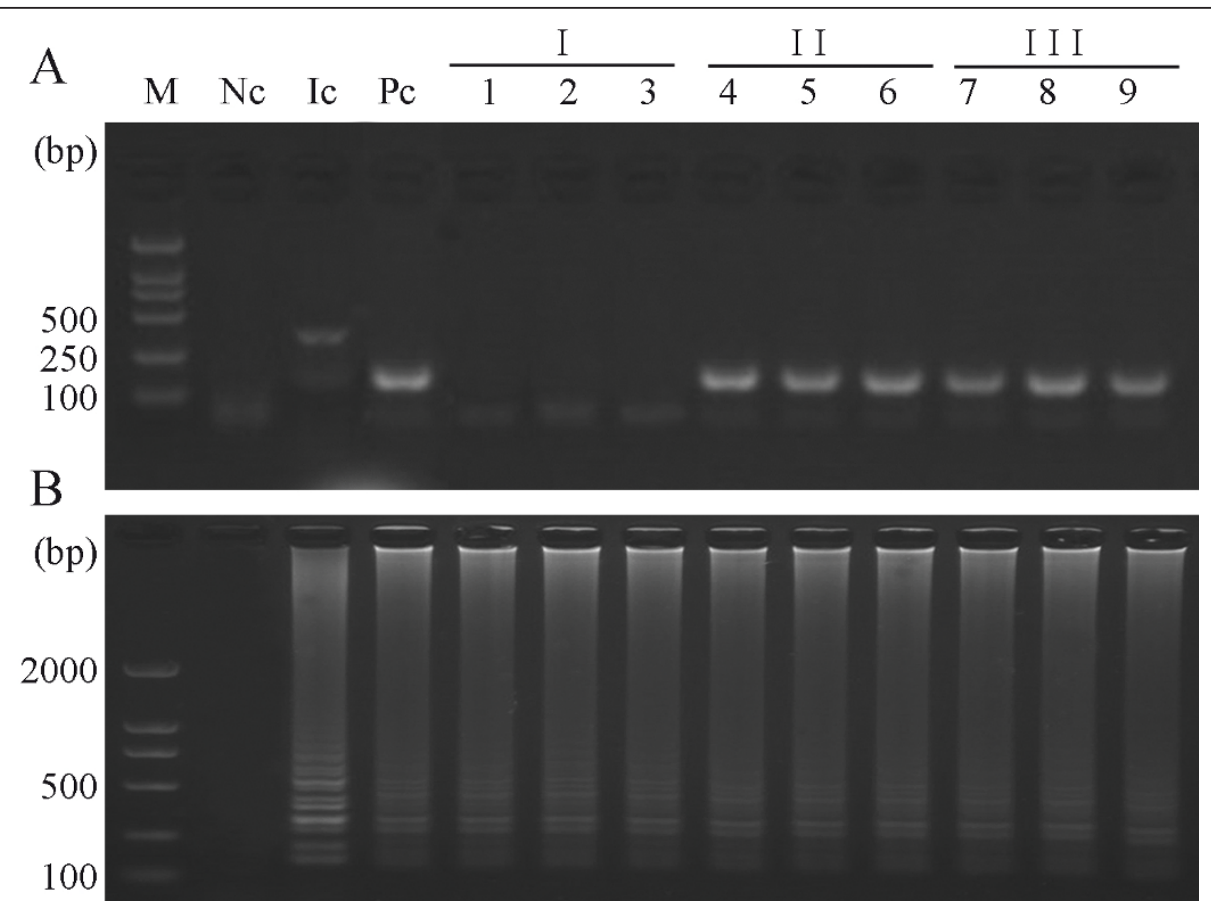

Figure 4 Analysis results of 9 blood samples from $\boldsymbol{T}$. gondii infected mice. (A) 529 bp-nested PCR; (B) 529 bp-LAMP. I, II, III represent three groups of BALB/C mice ( $n=3$ mice/group) that were infected by intraperitoneal injection with 20 virulent tachyzoites of $T$. gondii RH strain. Lane M represents 2,000 bp DNA ladder; lane Nc represents negative control; lane Ic represents internal control; lane Pc represents positive control; lanes 1-9 represent sample ID. Blood samples from mice were collected at 1, 3, and 5 days post injection.

assay for detection of T. gondii in blood samples, we tested, through LAMP assay and nested PCR, 28 blood samples obtained from nine infected mice with 20 virulent tachyzoites of the $T$. gondii $\mathrm{RH}$ strain and 19 normal mice. Six out of 28 blood samples were nested PCR-positive and nine out of 28 blood samples were LAMP-positive (Data not shown). The LAMP in this study revealed a sensitivity/specificity of $100 \%$ and a higher sensitivity than the nested PCR assays. These results showed that this assay should be considered as an early diagnostic tool for toxoplasmosis in mouse blood samples. They also demonstrated that the LAMP assay has a higher sensitivity than nested PCR for detection of T. gondii in blood samples.

The $529 b p$-LAMP assay was also applied to various organ samples including brain, heart, liver, spleen, kidney and lung from experimentally infected mouse. The assay showed positive results for heart samples at $1 \mathrm{dpi}$, for kidney samples at $3 \mathrm{dpi}$ and for all organ samples except the brain at $5 \mathrm{dpi}$ (Data not shown). Kaneko et $a l$. also reported that the specificity and sensitivity of LAMP detection does not seem to be impaired by sample type, including plasma, serum, PBS, saline, urine, aqueous humor and vitreous substances. The tolerance of LAMP for biological substances was very high $[34,35]$. Another advantage of the LAMP assay is that the requirements for LAMP are relatively simple, and that it does not require high technical skills or sophisticated equipments. However, there is a high risk of aerosol contamination due to the large amount of LAMP products. To reduce the risk of contamination, the LAMP partition in the laboratory, such as solution preparing partition, sample treatment partition, and gel electrophoresis detection partition, should be carried out in separate areas. Gloves should be changed regularly and sterile pipetting techniques should be applied during the entire LAMP experiment.

Here, we report a LAMP assay that specifically targets the 529 bp repeat element for the detection of $T$. gondii in mouse blood samples. We were able to demonstrate the successful amplification of $T$. gondii DNA at $1 \mathrm{dpi}$ within $1 \mathrm{~h}$ at $65^{\circ} \mathrm{C}$ using the LAMP assay. On the basis of these results, the LAMP assay can be considered one of the most accurate molecular assays because it is a specific, sensitive, and rapid diagnostic tool for the early detection of Toxoplasma in blood samples.

\section{Acknowledgements and Funding}

This work was supported by the National Important S\&T Project (2008ZX10004-011), Zhejiang Science and Technology Project (2007F30016, 2009F20036), the Projects of Zhejiang Health Department (XKQ-009-003, XKQ-010-001), and Zhejiang Provincial Program for the Cultivation of Highlevel Innovative Health Talents. We acknowledge Wang Yue at Zhejiang Academy of Medical Sciences for kindly providing the DNA of Plasmondium falciparum in the LAMP specificity experiment. 


\section{Author details}

Institute of Parasitic Diseases, Zhejiang Academy of Medical Sciences, Hangzhou 310013, China. ${ }^{2}$ Section of Environmental Parasitology, Department of International Health Development, Division of Public Health, Graduate School of Medical and Dental Sciences, Tokyo Medical and Dental University, Tokyo, Japan. ${ }^{3}$ National Institute of Parasitic Diseases, Chinese Center for Disease Control and Prevention, Shanghai, 200025, China.

\section{Authors' contributions}

$\mathrm{KQM}$ and TQB performed the main experiments and data analysis. KQM drafted the manuscript. LD, ZB and TK contributed to the initial phase of the experiments and assisted in the propagation of T. gondii tachyzoites. CR, WLY and NO helped conceive the research. LSH and ZXN created the detailed experimental design. All authors read and approved the final manuscript.

\section{Competing interests}

The authors declare that they have no competing interests.

Received: 30 March 2011 Accepted: 3 January 2012

Published: 3 January 2012

\section{References}

1. Xiao $Y$, Yin J, Jiang $N$, Xiang $M$, Hao L, Lu H, Sang H, Liu X, Xu H, Ankarklev J, Lindh J, Chen Q: Seroepidemiology of human Toxoplasma gondii infection in China. BMC Infect Dis 2010, 10:4.

2. Nissapatorn $V$ : Lessons learned about opportunistic infections in Southeast Asia. Southeast Asian J Trop Med Public Health 2008, 39:625-641.

3. Abu-Madi MA, Al-Molawi N, Behnke JM: Seroprevalence and epidemiological correlates of Toxoplasma gondii infections among patients referred for hospital-based serological testing in Doha, Qatar. Parasit Vectors 2008, 1:39.

4. Montoya JG, Liesenfeld O: Toxoplasmosis. Lancet 2004, 363:1965-1976.

5. Dubey JP: The history of Toxoplasma gondii-the first 100 years. J Eukaryot Microbiol 2008, 55:467-475.

6. Sharma S, Sandhu KS, Bal MS, Kumar H, Verma S, Dubey JP: Serological survey of antibodies to Toxoplasma gondii in sheep, cattle, and buffaloes in Punjab, India. J Parasito/ 2008, 94:1174-1175.

7. Dubey JP, Hill DE, Sundar N, Velmurugan GV, Bandini LA, Kwok OC, Pierce V, Kelly K, Dulin M, Thulliez P, Iwueke C, Su C: Endemic toxoplasmosis in pigs on a farm in Maryland: isolation and genetic characterization of Toxoplasma gondii. J Parasitol 2008, 94:36-41.

8. Dubey JP, Jones JL: Toxoplasma gondii infection in humans and animals in the United States. Int J Parasitol 2008, 38:1257-1278.

9. Tenter AM, Heckeroth AR, Weiss LM: Toxoplasma gondii: from animals to humans. Int J Parasitol 2000, 30:1217-1258.

10. Sensini A: Toxoplasma gondii infection in pregnancy: opportunities and pitfalls of serological diagnosis. Clin Microbiol Infect 2006, 12.504-512.

11. Montoya A, Miro G, Blanco MA, Fuentes I: Comparison of nested PCR and real-time PCR for the detection of Toxoplasma gondii in biological samples from naturally infected cats. Res Vet Sci 2010, 89:212-213.

12. Yang W, Lindquist HD, Cama V, Schaefer FW, Villegas E, Fayer R, Lewis EJ, Feng Y, Xiao L: Detection of Toxoplasma gondii oocysts in water sample concentrates by real-time PCR. Appl Environ Microbiol 2009, 75:3477-3483.

13. Lass A, Pietkiewicz H, Modzelewska E, Dumetre A, Szostakowska B, Myjak P: Detection of Toxoplasma gondii oocysts in environmental soil samples using molecular methods. Eur J Clin Microbiol Infect Dis 2009, 28:599-605.

14. Hierl T, Reischl U, Lang P, Hebart H, Stark M, Kyme P, Autenrieth IB: Preliminary evaluation of one conventional nested and two real-time PCR assays for the detection of Toxoplasma gondii in immunocompromised patients. J Med Microbiol 2004, 53:629-632

15. Pujol-Rique M, Derouin F, Garcia-Quintanilla A, Valls ME, Miro JM, Jimenez de Anta MT: Design of a one-tube hemi-nested PCR for detection of Toxoplasma gondii and comparison of three DNA purification methods. $J$ Med Microbiol 1999, 48:857-862

16. Maubon D, Brenier-Pinchart MP, Fricker-Hidalgo H, Pelloux $\mathrm{H}$ : [Real-time PCR in the diagnosis of toxoplasmosis: the way to standardisation?]. Pathol Biol (Paris) 2007, 55:304-311.

17. Calderaro A, Piccolo G, Gorrini C, Peruzzi S, Zerbini L, Bommezzadri S, Dettori G, Chezzi C: Comparison between two real-time PCR assays and a
nested-PCR for the detection of Toxoplasma gondii. Acta Biomed 2006 77:75-80.

18. Notomi T, Okayama H, Masubuchi H, Yonekawa T, Watanabe K, Amino N, Hase T: Loop-mediated isothermal amplification of DNA. Nucleic Acids Res 2000, 28:E63.

19. Wastling SL, Picozzi K, Kakembo AS, Welburn SC: LAMP for human African trypanosomiasis: a comparative study of detection formats. PLoS Negl Trop Dis 2010, 4:e865.

20. Iseki H, Kawai S, Takahashi N, Hirai M, Tanabe K, Yokoyama N, lgarashi I: Evaluation of a loop-mediated isothermal amplification method as a tool for diagnosis of infection by the zoonotic simian malaria parasite Plasmodium knowlesi. J Clin Microbiol 2010, 48:2509-2514.

21. Muller H, Aysul N, Liu Z, Salih DA, Karagenc T, Beyer D, Kullmann B, Ahmed JS, Seitzer U: Development of a loop-mediated isothermal amplification (LAMP) assay for rapid diagnosis of Babesia canis infections. Transbound Emerg Dis 2010, 57:63-65.

22. Aonuma H, Yoshimura A, Perera N, Shinzawa N, Bando H, Oshiro S, Nelson B, Fukumoto S, Kanuka H: Loop-mediated isothermal amplification applied to filarial parasites detection in the mosquito vectors: Dirofilaria immitis as a study model. Parasit Vectors 2009, 2:15.

23. Sotiriadou I, Karanis P: Evaluation of loop-mediated isothermal amplification for detection of Toxoplasma gondii in water samples and comparative findings by polymerase chain reaction and immunofluorescence test (IFT). Diagn Microbiol Infect Dis 2008, 62:357-365.

24. Zhang $\mathrm{H}$, Thekisoe OM, Aboge GO, Kyan $\mathrm{H}$, Yamagishi J, Inoue N, Nishikawa Y, Zakimi S, Xuan X: Toxoplasma gondii: sensitive and rapid detection of infection by loop-mediated isothermal amplification (LAMP) method. Exp Parasitol 2009, 122:47-50.

25. Krasteva D, Toubiana M, Hartati S, Kusumawati A, Dubremetz JF, Widada JS: Development of loop-mediated isothermal amplification (LAMP) as a diagnostic tool of toxoplasmosis. Vet Parasitol 2009, 162:327-331.

26. Lau YL, Meganathan P, Sonaimuthu P, Thiruvengadam G, Nissapatorn V, Chen Y: Specific, Sensitive and Rapid Detection of Active Toxoplasmosis in Patients by Loop-Mediated Isothermal Amplification (LAMP) Method in Blood Samples from patients. J Clin Microbiol 2010, 48:3698-3072.

27. Switaj K, Master A, Skrzypczak M, Zaborowski P: Recent trends in molecula diagnostics for Toxoplasma gondii infections. Clin Microbiol Infect 2005 11:170-176.

28. Burg JL, Grover CM, Pouletty P, Boothroyd JC: Direct and sensitive detection of a pathogenic protozoan, Toxoplasma gondii, by polymerase chain reaction. J Clin Microbiol 1989, 27:1787-1792.

29. Reischl U, Bretagne S, Kruger D, Ernault P, Costa JM: Comparison of two DNA targets for the diagnosis of Toxoplasmosis by real-time PCR using fluorescence resonance energy transfer hybridization probes. BMC Infect Dis 2003, 3:7.

30. Iseki H, Alhassan A, Ohta N, Thekisoe OM, Yokoyama N, Inoue N, Nambota A, Yasuda J, Igarashi I: Development of a multiplex loop-mediated isothermal amplification ( $\mathrm{mLAMP}$ ) method for the simultaneous detection of bovine Babesia parasites. J Microbiol Methods 2007, 71:281-287.

31. Alhassan A, Govind Y, Tam NT, Thekisoe OM, Yokoyama N, Inoue N, Igarashi I: Comparative evaluation of the sensitivity of LAMP, PCR and in vitro culture methods for the diagnosis of equine piroplasmosis. Parasitol Res 2007, 100:1165-1168

32. Thekisoe OM, Inoue N, Kuboki N, Tuntasuvan D, Bunnoy W, Borisutsuwan S, Igarashi I, Sugimoto C: Evaluation of loop-mediated isothermal amplification (LAMP), PCR and parasitological tests for detection of Trypanosoma evansi in experimentally infected pigs. Vet Parasitol 2005, 130:327-330.

33. Selvey S, Thompson EW, Matthaei K, Lea RA, Irving MG, Griffiths LR: Betaactin-an unsuitable internal control for RT-PCR. Mol Cell Probes 2001, 15:307-311.

34. Mori Y, Notomi T: Loop-mediated isothermal amplification (LAMP): a rapid, accurate, and cost-effective diagnostic method for infectious diseases. J Infect Chemother 2009, 15:62-69.

35. Kaneko H, Kawana T, Fukushima E, Suzutani T: Tolerance of loop-mediated isothermal amplification to a culture medium and biological substances. J Biochem Biophys Methods 2007, 70:499-501.

doi:10.1186/1756-3305-5-2

Cite this article as: Kong et al:: Loop-mediated isothermal amplification (LAMP): Early detection of Toxoplasma gondii infection in mice. Parasites \& Vectors 2012 5:2 